\title{
Home telework, travel behavior, and land-use patterns: A path analysis of British single-worker households
}

\author{
João de Abreu e Silva \\ Universidade de Lisboa \\ jabreu@tecnico.ulisboa.pt
}

\author{
Patricia C. Melo \\ Universidade de Lisboa \\ pmelo@iseg.ulisboa.pt
}

\begin{abstract}
This work analyzes the effects of home-based teleworking on the number of trips and weekly miles travelled by mode and purpose for one-worker households in Great Britain using data from the National Travel Survey for the period between 2005 and 2012. Two path analysis models are developed, one considering weekly trips and travel distances by mode and the other weekly trips and travel distances by purpose. Both models consider teleworking frequency in the context of home and workplace land-use characteristics, commuting distance, car ownership levels and weekly trips and travel distances. This framework allows us to explicitly model endogenous relations in the chains of decisions relating these variables. The results suggest that home-based teleworking is a strategy used by people to cope with long and costly commutes. Workers living in less transit accessible areas and with longer commutes tend to work from home more frequently. The main conclusions relating to teleworking frequency point to the fact that it increases weekly miles travelled, particularly by car, while it does not reduce commuting distances travelled. These results suggest that home-based teleworking is not an effective travel demand management strategy, particularly because it seems to increase car use. The overall main result is that teleworkers travel more by more polluting transport modes.
\end{abstract}

\section{Article history:}

Received: December 8, 2016

Received in revised form:

September 19, 2017

Accepted: January 30, 2018

Available online: July 2, 2018

Data availability: https://

discover.ukdataservice.ac.uk/

series/?sn $=2000037$

Copyright 2018 João de Abreu e Silva \& Patricia C. Melo

http://dx.doi.org/10.5198/jtlu.2018.1134

ISSN: 1938-7849 | Licensed under the Creative Commons Attribution - Noncommercial License 4.0

The Journal of Transport and Land Use is the official journal of the World Society for Transport and Land Use (WSTLUR) and is published and sponsored by the University of Minnesota Center for Transportation Studies. This paper is also published with additional sponsorship from WSTLUR. 


\section{$1 \quad$ Introduction}

Home-based telework ${ }^{1}$ rose to prominence in the last two decades of the 20th century mainly as a result of developments in information and communication technologies (ICT). Telework rapidly emerged as a possible travel demand management strategy, aimed at reducing congestion and negative environmental impacts of transportation. The main rationale behind it was that by working at home people would not have to commute to their work locations and thereby travel would be curtailed. In this manner, ICT was seen as substitute for physical travel. Although enthusiastically supported by at least some policymakers, scholars' views on the transportation impacts of home-based teleworking are mixed: some studies point to positive impacts (e.g., Kitamura, Nilles, Conroy, \& Fleming, 1991; Pendyala, Goulias, \& Kitamura, 1991; Helminen \& Ristimaki, 2007), while others consider it ineffective (e.g., Hjorthol \& Nossum , 2007; Zhu, 2012; Zhu \& Mason, 2014; He \& Hu, 2015). The reasons behind these differences might be related to study heterogeneity, i.e., different methodologies, sample sizes (small samples, e.g., Kitamura et al., 1991; Henderson, Koenig, \& Mokhtarian, 1996; and larger samples, e.g., Zhu, 2012; Zhu \& Mason, 2014; Kim, Choo, \& Mokhtarian, 2015), and the use of travel diaries ranging from one to several days, among other factors.

Home-based telework also has implications in terms of land use patterns and the home and workplace location choices of teleworkers, particularly because teleworkers tend to have longer commuting distances than other workers (Wells, Douma, Loimer, Olson, \& Pansing, 2001; Mokhtarian, Collantes, \& Gertz, 2004; Zhu, 2012, 2013). Regarding this aspect, there is contention about the direction of causality. Does it stem from commuting distance to telework? - meaning that telework is a strategy used by people to reduce commuting burden, or is it another opportunity for households to move to peripheral urban areas, thus contributing to sprawl? These issues guide the present research, which aims to study the effects of home-based telework frequency on weekly travel by mode and purpose. Telework frequency is modelled in the context of home and workplace urban characteristics, commuting distance and the number of trips and miles travelled during a whole week (to account for possible shifts of travel during different weekdays). The data used refers to a sample of single-worker households collected from the National Travel Survey (NTS) in Great Britain, between 2005 and 2012.

This paper is organized as follows. In the next section a literature review is offered. It focuses mainly on the following aspects: impacts of teleworking on travel; relationships between teleworking, land use patterns and location choices; causality between commuting distance, residential and workplace location choices and teleworking; and factors affecting the decision to work from home. Section 3 presents the conceptual framework underlying the empirical analysis, while Section 4 describes the data and variables. Section 5 briefly describes the modeling method, and is followed by the discussion of the results in Section 6. The paper ends with the conclusions and a brief discussion about further research in Section 7.

\section{$2 \quad$ Literature review}

\subsection{Impacts of home telework on travel}

One of the most important streams of research refers to the potential impacts of teleworking on the total amount of travel, and its subsequent effects on the environment. Although ICT in general, and teleworking in particular, can reduce travel costs and time, these savings may be used for engaging in other

${ }^{1}$ The term telework is a synonym of telecommuting. Telework or telecommuting could be either home-based, meaning that people work remotely from home, or center-based where people commute to a telework center and work remotely from there. 
activities which might include travel (Mokhtarian, 2009), thus offsetting some of its benefits. Early studies were mainly positive about the potential benefits of teleworking, with several reporting a reduction in the number of trips and miles driven by teleworkers (Hamer, Kroes, \& Oosttsroom, 1991; Kitamura et al., 1991; Pendyala, Goulias, \& Kitamura, 1991; Nilles, 1991; Mokhtarian, Handy, \& Salomon, 1995; Henderson et al., 1996; Choo, Mokhtarian, \& Salomon, 2005; Helminen \& Ristimaki, 2007). Some studies also reported travel reductions at the level of the household (Nilles, 1991; Mokhtarian et al., 1995). Later studies tended to conclude the opposite, or at least that the gains were not as expressive as was initially thought (Nelson, Safirova, \& Walls, 2007; Hjorthol \& Nossum, 2007; Zhu, 2012; Zhu \& Mason, 2014; He \& Hu, 2015; Kim et al., 2015). In addition, some recent studies concluded that households with teleworkers travel more than other households (Zhu \& Mason, 2014; Melo \& de Abreu e Silva, 2017) and that teleworkers have bigger travel budgets (Zhu, 2012).

There is also evidence that workers who engage in teleworking tend to have smaller activity spaces (Pendyala et al., 1991) because their activities tend to be clustered around home on the days they work from home, contrary to what happens on the other (commuting) days where their activities tend to be oriented towards the employment area (Saxena \& Mokhtarian, 1997). Furthermore, because teleworkers tend to live in more suburban areas, usually associated with lower levels of transit supply, there is a higher likelihood that their trips on teleworking days are made by car (Yen, 2000). As a result, teleworking might contribute to decentralizing travel rather than reduce it (Kim et al., 2015). This view is concurrent with the conclusions from studies which found that teleworkers are more frequent car users (Wells et al., 2001; Hjorthol \& Nossum, 2007; Zhu \& Mason, 2014). Regarding travel purposes teleworkers tend to engage in more business and non-work trips than non-teleworkers (Zhu, 2012; Kim et al., 2015).

\subsection{Impacts of home telework on land-use patterns and location choice}

Teleworker households tend to be located in the periphery of cities (Kim, Mokhtarian, \& Ahn, 2012) and have longer commutes (Wells et al., 2001; Mokhtarian et al., 2004; Zhu, 2012, 2013). Although several authors refer to commuting distance, or time, as one relevant reason to adopt home-based teleworking (Yen, 2000; Mokhtarian \& Bagley, 2000; Mokhtarian et al., 2004; Nurul Habib, Sasic, \& Zaman, 2012), the latter can allow workers to live further away from their jobs thereby contributing to sprawl and longer commutes (Nilles, 1991; Mokhtarian, 2009). In the long term, this relocation of households to the periphery can reduce the transportation benefits of teleworking (Lund \& Mokhtarian, 1994). Other forces might also come into play since teleworking can increase both residential and workplace location flexibility (Tavyaran \& Khan, 2003). Teleworking might contribute to the dispersion of employment, leading to the reduction of teleworkers commuting distances, but it could also result in the centralization of urban activities (Rhee, 2008). These possibilities, derived from theoretical urban models, are in some way validated by an empirical study in Seoul where it was found that teleworkers' commuting distance is shorter than for non-teleworkers, which could be explained by the transfer of jobs to the suburbs (Kim et al., 2012).

\subsection{Causality between home telework and commuting distance}

There is ongoing debate on the direction of causality between home telework and commuting distance. Assuming households minimize commuting and housing costs, one would expect the causal direction to go from teleworking to home location (Tavyaran \& Khan, 2003; Zhu, 2013; Zhu \& Mason, 2014;), since teleworking can reduce commuting costs and allow people to move to the periphery where housing costs are lower. Nevertheless, several studies focusing on the decision to telework hint at a reverse 
relationship, proposing that it is the commuting cost, or time, that increase the likelihood to engage in home telework (Yen, 2000; Wells, et al., 2001; Peters, Tijdens, \& Wetzels, 2004; Helminen \& Ristimaki, 2007; Kim et al., 2012). These conclusions are reinforced by Ory and Mokhtarian (2006), who studied retrospectively 200 state workers in California. They found that people who always teleworked tended to move closer to their workplace, while those who moved further away from their workplace only tended to start teleworking after the move. In addition, teleworking did not appear to be relevant enough to affect home relocation decisions (Ory \& Mokhtarian, 2006). Other empirical studies also found that teleworking was not a significant factor in home relocation decisions (Muhammad, Ottens, Ettema, \& de Jong, 2007; Ettema, 2010). However, and despite the fact that teleworkers cannot be considered as an uniform group regarding their residential preferences, a positive association between being a teleworker and having suburban living preferences has been found by some studies (Ettema, 2010). Although there is a theoretical rationale to consider that teleworking influences home (and work) location, the empirical studies reviewed here concluded otherwise, that is, teleworking is mainly a strategy to cope with long and costly commutes. Furthermore, since home location can be considered a long term decision, which because of its transaction costs is much more difficult to reverse than the decision to telework (Giuliano, 1989; Golledge \& Garling, 2003), it could also be argued that at least in the short term the direction of causality is more likely to run from commuting distance to home telework.

\subsection{Other factors influencing the adoption of home telework}

Several socioeconomic attributes were found to be associated with telework adoption, namely higher education levels (de Graaff \& Rietvelt, 2004; Hjorthol \& Nossum, 2007) and higher income (He \& $\mathrm{Hu}, 2015)$. People working in managerial/professional occupations are also more likely to telework than those working in other activities, namely in sales (Hjorthol \& Nossum, 2007; Singh, Paleti, Jenkins, \& Bhat, 2013). The results are mixed for gender and age. Whereas Peters et al. (2004) found no differences in the predisposition to telework between men and women, other authors contend that being a man influences the likelihood to engage in telework (Poury \& Bhat, 2003; Hjorthol \& Nossum, 2007). Regarding age, de Graaff and Rietvelt (2004) found that younger people are more willing to telework, whereas Poury and Bhat (2003) concluded otherwise. These contradictory findings might be related to the types of functions different workers perform and their specific compatibility with telework. Whereas younger people are generally more at ease with ICT, and therefore more apt to telework, older people might hold managerial functions which are also more compatible with teleworking.

Household and location related characteristics also influence the decision to telework. Peters et al. (2004) found that the presence of children in households reduces the propensity to telework, but house size is a relevant positive influence (Yen, 2000). Since bigger living space is usually associated with living in suburban areas, this implies that, besides reinforcing the connection between commuting distance and telework, it may also reinforce the role of built environment characteristics on the decision to telework (Singh et al., 2003). However, Singh et al. (2003) also found a positive relationship between living in more urbanized areas and teleworking. This could be due mainly to better access to ICT devices and infrastructures in more urbanized areas. It could also mean that while teleworkers may be more likely to reside in the suburbs of large urban areas, their sprawl to the countryside is more difficult.

Travel behavior can also influence the decision to telework. People who commute by transit are more likely to engage in telework and are more sensitive to transit attributes (fares, travel times and access/egress times) than their car commuting counterparts (Yen, 2000; Nurul Habib, Sasic \& Zaman, 2012). These findings have potential negative effects for transport policy since they could spell reductions in transit patronage and higher mode shares for car. Individual preferences may impact on the decision to adopt home telework. People who perceive commuting as a burden are more inclined to 
engage in teleworking (Mokhtarian \& Salomon, 1997; Mokhtarian \& Bagley, 2000). Social influence (Paez \& Scott, 2007) and feedback effects from past behavior (Salomon, 1998) were also found to influence telework adoption.

\section{Conceptual framework}

The main research questions addressed in this work relate to the effects of home-based telework on weekly travel by mode or purpose, and how the land use characteristics of residence and employment areas affect these relationships. To answer these questions, we developed a modelling framework for the relationship between home telework frequency, land use patterns of residence and employment areas, and long- and short-term travel behavior. Long-term relationships include location decisions, commuting distance and car ownership, whereas short-term decisions include the number of weekly trips and the number of weekly distance travelled by mode or purpose. Figure 1 presents the conceptual model, which is described below.

Telework frequency was included in a modelling framework that relates land use patterns both at the residence and employment locations with commuting distance, household car ownership and the amount of weekly travel. The original framework, without home telework, has been applied to different cities in previous studies and resulted in similar outcomes and conclusions (de Abreu e Silva, Golab, \& Goulias, 2006; de Abreu e Silva, Morency, \& Goulias, 2012), thereby reinforcing its robustness. To the best of our knowledge this is the first time that home telework frequency has been included in a model explicitly incorporating location decisions, and long- and short-term travel behavior decisions.

Building a model that can incorporate both travel purposes and modes creates daunting difficulties (this model would have 18 equations describing travel as compared to the 6 in the case of the present models). Therefore, we opt for the estimation of two separate models, one considering travel by mode and the other travel by purpose. The model focusing on weekly travel by mode (i.e., car, transit, active modes) investigates possible patterns of substitution between different transport modes, particularly between car use, public transport and active travel. It will allow us to examine the influence of teleworking frequency on car use, while at the same time controlling for other relevant determinants of modal choice like land use characteristics and car ownership. If, as Pendyala et al. (1991) and Saxena and Mokhtarian (1997) suggested, the activity spaces of teleworkers tend to be smaller and centered around home in the days they telework, then the trips made in these days could favor the use of modes more adapted to the transport and land use characteristics of residential locations, possibly car and active modes. The model for weekly travel by purpose (i.e., commuting, business, non-work) allows us to examine if the likely reduction in commuting trips due to home-based telework could be offset by the longer one-way commuting distance of teleworkers, and its effects on total weekly commuting distance. Importantly, this model also highlights the possible effects that savings in commuting travel might have on other activities (work and non-work related) that lead to additional travel, as hypothesized by Mokhtarian (2009). These two models can also be used to test the hypothesis that teleworkers have larger travel budgets than non-teleworkers, as advanced by Zhu, (2012).

The conceptual framework considers that the land use characteristics surrounding both the residence and the workplace are endogenous, and thus specified as a function of socioeconomic and demographic attributes of the individuals, their households, and travel behavior decisions, which in turn accounts for self-selection effects due to either specific needs or preferences of the respondents and their households. Both land use characteristics and socioeconomic variables affect commuting distance and car ownership. Frequency of teleworking is considered to be a shorter term travel decision, and therefore was modelled as a function of the longer term travel decisions and socioeconomic attributes. However, 
since existing literature on the relationship between commuting distance and home telework also suggests that the effect could be reversed (i.e., the possibility of teleworking could influence residential location to more remote areas: e.g., Zhu, 2013; Zhu \& Mason, 2014) both specifications were tested, as well as a non-recursive specification where both directions of causality are considered. Finally, the variables representing longer term decisions (home and work location characteristics, commuting distance and car ownership) influence the number of weekly trips and travel distances either by mode or by purpose, which are considered to be short-term decisions. The conceptual framework also considers feedback effects, whereby shorter term travel behavior variables could influence commuting distance or location patterns of individuals.

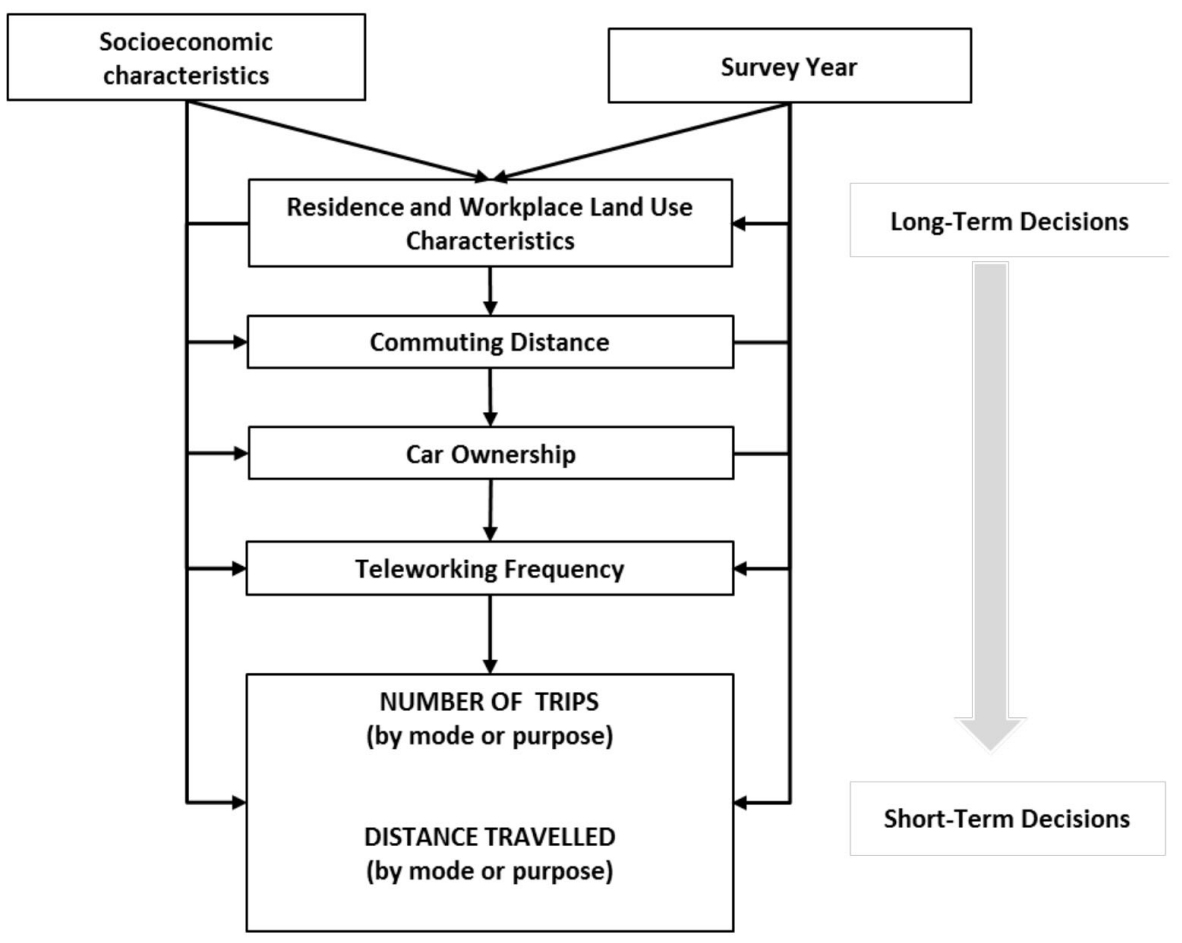

Figure 1: Conceptual model of the relationships between home telework, travel behavior, and land use

\section{$4 \quad$ Data and variables}

The data were obtained from Great Britain's National Travel Survey (NTS) for the period between 2005 and 2012. The NTS is a stratified multi-stage random sample face-to-face travel survey of British households and has been carried on a yearly basis since 1988. The survey collects data for trip diaries for each surveyed household during a 7-day period. The sample used in this study comprises workers from single-worker households, who reported working in the same place at least two days a week, are not selfemployed in single worker companies and who do not work in agriculture or fisheries. Single-worker households, besides being easier to model, represent $44.7 \%$ of the households with workers in the NTS sample, making them a relevant segment. The sample size is 10,516 observations. Table 1 presents the variables used in the empirical analysis, their mean values and standard deviations, or frequencies, and their role in the model (endogenous or exogenous). 
Table 1: Descriptive statistics of demographic, socioeconomic, and travel variables

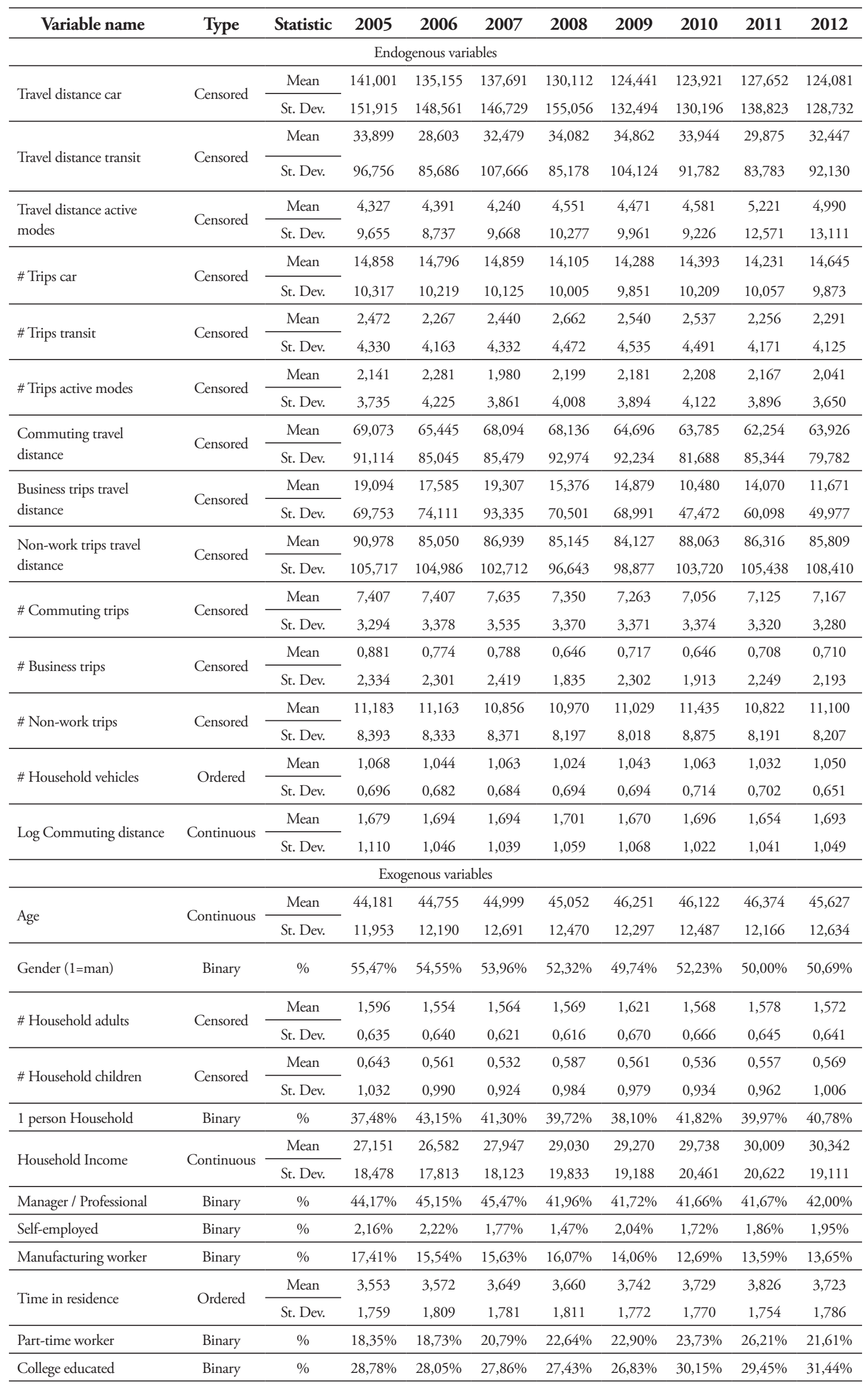


Table 2 shows there has been an increase in home-based teleworking between 2005 and 2012, particularly for those teleworking three or more times per week, which more than doubled. These figures are in accordance with NTS data for the full sample of workers (i.e., not just the sub-sample of singleworker households considered in this study; see Melo \& de Abreu e Silva, 2017). Nevertheless, the vast majority of workers (around 82\% in 2012) were not involved in home-based teleworking.

Table 3 shows that the relation between travel and one-way commuting distance and teleworking is not linear. It is possible to devise a general mobility and commuting distance growth tendency as the frequency of teleworking increases. However, for the highest frequency of teleworking there is a decrease in commuting distance and weekly travelled distances for all purposes and modes, with the exception of active modes. The more frequent teleworkers also have a higher number of weekly trips by active modes and business and non-work trips.

Table 2: Summary descriptive statistics of home telework frequency

\begin{tabular}{cccccccc}
\hline \multicolumn{7}{c}{ Teleworking frequency } \\
\hline Year & $\begin{array}{c}\text { Less than } \\
\text { once a } \\
\text { year }\end{array}$ & $\begin{array}{c}\text { Once or } \\
\text { twice a } \\
\text { year }\end{array}$ & $\begin{array}{c}\text { Less than once a } \\
\text { month but more } \\
\text { than twice a year }\end{array}$ & $\begin{array}{c}\text { Once or } \\
\text { twice a } \\
\text { month }\end{array}$ & $\begin{array}{c}\text { Less than once a } \\
\text { week but more than } \\
\text { twice a month }\end{array}$ & $\begin{array}{c}\text { Once or } \\
\text { twice a week }\end{array}$ & $\begin{array}{c}3 \text { or more } \\
\text { times a week }\end{array}$ \\
\hline 2005 & $88.8 \%$ & $1.7 \%$ & $1.8 \%$ & $3.5 \%$ & $1.6 \%$ & $2.4 \%$ & $0.3 \%$ \\
2006 & $89.1 \%$ & $1.6 \%$ & $1.9 \%$ & $3.3 \%$ & $0.7 \%$ & $2.8 \%$ & $0.6 \%$ \\
2007 & $88.9 \%$ & $2.1 \%$ & $2.3 \%$ & $3.4 \%$ & $1.1 \%$ & $1.8 \%$ & $0.4 \%$ \\
2008 & $88.9 \%$ & $2.0 \%$ & $2.1 \%$ & $3.8 \%$ & $0.7 \%$ & $2.0 \%$ & $0.5 \%$ \\
2009 & $84.8 \%$ & $3.2 \%$ & $4.0 \%$ & $3.6 \%$ & $1.2 \%$ & $2.3 \%$ & $0.9 \%$ \\
2010 & $85.0 \%$ & $2.7 \%$ & $3.2 \%$ & $3.6 \%$ & $1.5 \%$ & $3.6 \%$ & $0.4 \%$ \\
2011 & $85.2 \%$ & $2.9 \%$ & $3.3 \%$ & $3.7 \%$ & $1.1 \%$ & $3.6 \%$ & $0.2 \%$ \\
\hline
\end{tabular}

Table 3: Travel patterns by home telework frequency

\begin{tabular}{lccccccc}
\hline \multicolumn{1}{c}{ Teleworking frequency } \\
\hline $\begin{array}{c}\text { Travel } \\
\text { variables } \\
\text { (mean } \\
\text { values) }\end{array}$ & $\begin{array}{c}\text { Less than } \\
\text { once a } \\
\text { year }\end{array}$ & $\begin{array}{c}\text { Once or } \\
\text { twice a } \\
\text { year }\end{array}$ & $\begin{array}{c}\text { Less than once } \\
\text { a month but } \\
\text { more than twice } \\
\text { a year }\end{array}$ & $\begin{array}{c}\text { Once or } \\
\text { twice a } \\
\text { month }\end{array}$ & $\begin{array}{c}\text { Less than once } \\
\text { a week but } \\
\text { more than } \\
\text { twice a month }\end{array}$ & $\begin{array}{c}\text { Once or } \\
\text { twice a } \\
\text { week }\end{array}$ & $\begin{array}{c}\text { 3 or more } \\
\text { times a } \\
\text { week }\end{array}$ \\
\hline $\begin{array}{l}\text { Travel } \\
\text { distance car } \\
\text { (miles) }\end{array}$ & 122.020 & 184.010 & 179.890 & 201.550 & 206.920 & 183.520 & 123.670 \\
\hline $\begin{array}{l}\text { Travel dis- } \\
\text { tance transit } \\
\text { (miles) }\end{array}$ & 26.790 & 59.860 & 69.650 & 78.690 & 60.740 & 80.560 & 22.240 \\
\hline $\begin{array}{l}\text { Travel } \\
\text { distance } \\
\text { active modes } \\
\text { (miles)s }\end{array}$ & 4.460 & 5.760 & 6.040 & 4.920 & 6.880 & 4.120 & 6.130 \\
\hline \# Trips car & 14.440 & 15.340 & 15.410 & 15.310 & 15.220 & 14.590 & 13.540 \\
\hline \# Trips & 2.350 & 3.000 & 3.080 & 3.140 & 2.840 & 2.750 & 2.300 \\
transit & & & & & & & \\
\hline $\begin{array}{l}\text { \# Trips } \\
\text { active modes }\end{array}$ & 2.150 & 2.210 & 2.280 & 1.910 & 2.400 & 1.790 \\
\hline
\end{tabular}




\begin{tabular}{|c|c|c|c|c|c|c|c|}
\hline \multicolumn{8}{|c|}{ Teleworking frequency } \\
\hline $\begin{array}{c}\text { Travel } \\
\text { variables } \\
\text { (mean } \\
\text { values) }\end{array}$ & $\begin{array}{c}\text { Less than } \\
\text { once a } \\
\text { year }\end{array}$ & $\begin{array}{c}\text { Once or } \\
\text { twice a } \\
\text { year }\end{array}$ & $\begin{array}{l}\text { Less than once } \\
\text { a month but } \\
\text { more than twice } \\
\text { a year }\end{array}$ & $\begin{array}{l}\text { Once or } \\
\text { twice a } \\
\text { month }\end{array}$ & $\begin{array}{l}\text { Less than once } \\
\text { a week but } \\
\text { more than } \\
\text { twice a month }\end{array}$ & $\begin{array}{c}\text { Once or } \\
\text { twice a } \\
\text { week }\end{array}$ & $\begin{array}{c}3 \text { or more } \\
\text { times a } \\
\text { week }\end{array}$ \\
\hline $\begin{array}{l}\text { Commut- } \\
\text { ing travel } \\
\text { distance } \\
\text { (miles) }\end{array}$ & 60.152 & 91.413 & 93.852 & 107.509 & 109.399 & 120.624 & 50.670 \\
\hline $\begin{array}{l}\text { Business } \\
\text { trips travel } \\
\text { distance } \\
\text { (miles) }\end{array}$ & 11.630 & 36.249 & 37.529 & 50.870 & 45.437 & 34.943 & 12.628 \\
\hline $\begin{array}{l}\text { Non-work } \\
\text { trips travel } \\
\text { distance } \\
\text { (miles) }\end{array}$ & 81.400 & 121.876 & 124.133 & 126.673 & 119.576 & 112.551 & 88.628 \\
\hline $\begin{array}{l}\text { \# Commut- } \\
\text { ing trips }\end{array}$ & 7.410 & 7.270 & 7.010 & 6.770 & 6.600 & 5.740 & 5.370 \\
\hline $\begin{array}{l}\text { \# Business } \\
\text { trips }\end{array}$ & 0.630 & 1.310 & 1.330 & 1.560 & 1.500 & 1.430 & 1.740 \\
\hline $\begin{array}{l}\text { \# Non-work } \\
\text { trips }\end{array}$ & 10.910 & 11.970 & 12.430 & 12.020 & 12.350 & 11.960 & 12.170 \\
\hline $\begin{array}{l}\text { One-ways } \\
\text { commuting } \\
\text { distance } \\
\text { (miles) }\end{array}$ & 4,932 & 8,330 & 8,581 & 10,332 & 11,306 & 11,635 & 6,170 \\
\hline
\end{tabular}

The variables describing land use features and transport accessibility of residence and work locations were obtained both from the NTS and from external data sources. NTS data for residence and work locations are available at different geographical levels. Data for residential locations are available at the level of Primary Sampling Units (PSU), which corresponds to a postcode sector, but also for more aggregate levels such as wards and unitary authorities (UAs). On the other hand, data for employment locations are available only at the level of unitary authorities. The NTS also collects data on respondents' perceptions about accessibility to public transport (i.e., nearest bus stop, nearest train station) and frequency of services close to their residence. These data were complemented by additional external (i.e., not in NTS) data relating to the number and density of jobs in the employment UAs, as well as the density of roads and train stations in the residence ward. Based on these variables, a principal components factor analysis technique was employed, which resulted in six factors explaining $68.5 \%$ of the total variation. These factors, together with their defining variables and respective scores, are presented in Table 4.

Table 4: Principal components factor analysis of land-use factors $(\mathrm{KMO}=0.731)$

\begin{tabular}{llc}
\hline \multicolumn{1}{c}{ Land use factor } & \multicolumn{1}{c}{ Most important variables } & Loadings \\
\hline & Population density (primary sampling unit of residence) & 0.832 \\
& Population density (local authority of residence) & 0.774 \\
& Bus frequency in the residence area & 0.681 \\
& Minor roads density (ward of residence) & 0.809 \\
\hline \multirow{2}{*}{$\begin{array}{l}\text { (2) Working in London or other dense } \\
\text { urban centers }\end{array}$} & Working in London central area x number of jobs in the working & 0.980 \\
& unitary authority $\left.{ }^{*}\right)$ & 0.980 \\
\hline
\end{tabular}




\begin{tabular}{llc}
\hline \multicolumn{1}{c}{ Land use factor } & \multicolumn{1}{c}{ Most important variables } & Loadings \\
\hline \multirow{2}{*}{ (3) Living in a rail accessible area } & Walking time to the closest rail station (residence area) & -0.697 \\
& Rail stations density (residence ward) & 0.743 \\
\hline \multirow{2}{*}{ (4) Living in a low transit accessible area } & Walking time to the closest bus stop (residence area) & 0.721 \\
& Travel time in bus to the closest rail station (residence area) & -0.719 \\
\hline \multirow{2}{*}{$\begin{array}{l}\text { (5) Working in metropolitan suburbs and } \\
\text { living in a freeway accessible area }\end{array}$} & $\begin{array}{l}\text { Working in a metropolitan centre outer area x number of jobs in } \\
\text { the working unitary authority }(*)\end{array}$ & 0.689 \\
& Motorway density in the residence ward & 0.714 \\
\hline \multirow{2}{*}{ 6) Working in the countryside } & $\begin{array}{l}\text { Working in small urban areas(3k-25k inhabitants) x number of } \\
\text { jobs in the working unitary authority }\end{array}$ & -0.671 \\
& Working in rural areas x number of jobs in the working unitary & 0.777 \\
\hline$\left.{ }^{*}\right)$ Interaction effects between the working area and the number of jobs & \\
\hline
\end{tabular}

From the resulting six factors, three are mainly related with the characteristics of the residence area, two with the employment area, and one is related both with the residence and employment areas. The first factor, named Living in a denser area has high loadings in density variables, bus frequency and minor roads density. The second factor is associated with working in London or other dense job centers. The third and fourth factors are related with the level of accessibility to both rail and bus services in the vicinity of the residence, and capture both zones with high accessibility to rail and zones with low levels of bus accessibility. The fifth factor captures the joint characteristics of living in areas with high accessibility by freeway and working in the suburbs of metropolitan areas. Finally, the sixth factor has strong loadings on the interaction between the number of jobs and working either in rural areas or in small urban areas. It was named Working in the countryside.

\section{$5 \quad$ Methodology}

The modelling approach used here is path analysis, which is a special case of Structural Equation Modelling (SEM) when all variables included in the different model equations are observed. The general equation for this method is as follows:

$$
y=B y+\Gamma_{x}+\zeta
$$

where:

$\mathrm{y}$ is the vector of the endogenous variables;

$\mathrm{B}$ is the matrix containing the coefficients for the equations relating the endogenous variables;

$\mathrm{X}$ is the vector of the exogenous variables;

$\Gamma$ is the matrix containing the coefficients for the equations relating the exogenous with the endogenous variables;

$\zeta$ is the vector of the residuals from the structural relationships between $\mathrm{y}$ and $\mathrm{x}$.

The fact that this method is able to model simultaneously several endogenous variables and handle direct and indirect relationships makes it particularly adequate to study complex relationships between travel behavior and the urban environment (for more details about SEM see, for example, Kaplan, 2000; Bollen, 1989). The model results include direct (equivalent to regression coefficients), indirect (sum of the effects mediated by other variables) and total effects (sum of the direct and indirect effects). Direct effects give a clear image about the model structure, but the total effects allow for a better interpretation, since 
due to possible contradictory direct and indirect effects, model interpretation based only in the direct effect might lead to misleading conclusions.

The estimation method used is the Weighted Least Squares (WLS). This method was developed to deal with binary, ordered and censored variables (Golob, 2003), as is the case of our data. Since WLS uses correlation matrices, the resulting coefficients are standardized, facilitating a direct comparison between the magnitudes of the different effects.

\section{Results and discussion}

\subsection{Causality between home telework and commuting distance}

As discussed previously, one of the key issues in the study of the relations between teleworking, land use patterns and travel behavior is the direction of causality between teleworking and commuting distance. The modelling method, path analysis, is used to test theoretical relationships, but it cannot establish causal relationships unless the conditions of temporal ordering, correlation and control for other causes are met (Schumaker \& Lomax, 2004). In the case of our study it is basically temporal ordering that is missing, since the data comes from eight years of cross-sectional travel surveys. Nevertheless, it is possible to test different model specifications, compare them, and based on the model fit indicators and the arguments laid out in the literature, opt for one specification.

Since both models used share a common part (the only difference in their structure relates to the endogenous variables for the travel modes and travel purposes), three different alternatives were tested for the common component: a) teleworking frequency is a function of commuting distance, b) the reverse relation is considered, and c) a simultaneous bidirectional relationship between commuting distance and teleworking frequency (non-recursive model). To compare these models four goodness-of-fit indicators where considered, namely, the chi-square statistic (and its p-value), the Akaike Information Criterion (AIC), the Consistent Akaike Information Criterion (CAIC), and the Expected Cross Validation Index (ECVI) together with its 90\% confidence interval. The model with the lowest values for the three last indicators should be the preferred one (Kaplan, 2000; Schermelleh-Engel, Moosbrugger, \& Müller, 2003). The results are presented in Table 5. With the exception of the chi-square statistic (although the implied p-value is almost identical to the one for alternative c), which has the smaller chisquared statistic), all the fit indicators support the choice of alternative a), that is, teleworking frequency as a function of commuting distance, as the preferred specification. However, the fit indicators are not fully conclusive, since the confidence intervals of ECVI have some overlap. Also, in the case of specification c) the coefficient for the effect of commuting distance on telework is negative and non-significant. From these indicators and the discussion presented earlier we have opted for specifying home telework as a function of commuting distance.

Table 5: Comparison between the different model specifications

\begin{tabular}{lcccc}
\hline \multicolumn{1}{c}{ Model specification } & $\begin{array}{c}\text { Chi-square } \\
\text { (p-value) }\end{array}$ & AIC & CAIC & $\begin{array}{c}\text { ECVI } \\
\text { [90\% confidence interval] }\end{array}$ \\
\hline $\begin{array}{l}\text { a) - Teleworking function of commut- } \\
\text { ing distance }\end{array}$ & $\begin{array}{l}114.841 \\
(0.0143)\end{array}$ & 452.841 & 1848.892 & $\begin{array}{c}0.0431 \\
{[0.0408 ; 0.0462]}\end{array}$ \\
\hline $\begin{array}{l}\text { b) - Commuting distance function of } \\
\text { teleworking }\end{array}$ & $\begin{array}{l}120.844 \\
(0.0053)\end{array}$ & 458.844 & 1854.894 & $\begin{array}{c}0.0437 \\
{[0.0413 ; 0.0469]}\end{array}$ \\
\hline $\begin{array}{l}\text { c) - bidirectional relationship between } \\
\begin{array}{l}\text { commuting distance and teleworking } \\
\text { (non-recursive relationship) }\end{array}\end{array}$ & $\begin{array}{l}113.657 \\
(0.0144)\end{array}$ & 453.657 & 1857.868 & 0.0432 \\
\hline
\end{tabular}




\subsection{Goodness of fit of models by travel mode and travel purpose}

Both model specifications (travel modes and travel purposes) present good levels of fit, as can be seen from Table 6 for the following fit indicators: the Chi-square statistic, respective p-value, the RMSEA and the Test of Close Fit (RMSEA<0.05), and both Bayesian fit indicators AIC and CAIC. The ratio between the chi-square and the degrees of freedom, close to 1 for both models, is also indicative of a good fit (Schermelleh-Engel et al., 2003; Jöreskog \& Sörbom, 1993). In addition, the RMSEA values indicate a good fit (Schermelleh-Engel et al., 2003) and the values for AIC and CAIC are smaller than the values for both the saturated and independence models, indicating that the estimated models are superior to these.

Table 6: Summary of goodness of fit indicators of the SEM analysis

\begin{tabular}{lcc}
\hline \multicolumn{1}{c}{ Goodness of fit indicators } & Model travel modes & Model travel purposes \\
\hline Chi-square & 183,487 & 173,157 \\
\hline \# degrees of freedom & 181 & 185 \\
\hline p-value & 0,434 & 0,724 \\
\hline RMSEA & 0,0011 & 0,000 \\
\hline p-value (test of close fit) & 1,000 & 1,000 \\
\hline AIC & 633,487 & 615,157 \\
\hline CAIC & 2492,134 & 2440,762 \\
\hline
\end{tabular}

\subsection{Effects on weekly travel due to the exogenous variables}

Table 7 and Table 8 report both the standardized direct and total effects of the exogenous variables obtained from the models of weekly travel by mode and by purpose, respectively. Globally, both models are able to capture the effects from socioeconomic characteristics on travel variables as predicted in the literature. Higher household income levels are associated with increased travel by (private and transit) motorized modes and for the different purposes (i.e., commuting, business, non-work). Weekly travelled distances are higher for men for each type of travel mode and purpose, with the exception of nonwork related travel, which is higher for women. This suggests that women may spend more time than men travelling for non-work reasons (e.g., shopping, escorting children to school). Car ownership levels are also influenced by the exogenous variables, namely, household income and the number of adults in the household. The results also support the existence of self-selection of residential and working location on individual and household socioeconomic characteristics.

With respect to the factors affecting home telework frequency, the models suggest that younger, male workers with a college degree belonging to smaller households with higher income levels are more likely to engage in telework more frequently. This is in accordance with what has been reported previously (e.g., de Graaff \& Rietvelt, 2004; Poury \& Bhat, 2003; Hjorthol \& Nossum, 2007; He \& Hu, 2015). House tenure duration is positively related with telework frequency, supporting the argument that teleworking is in great part a strategy to cope with longer commutes. 


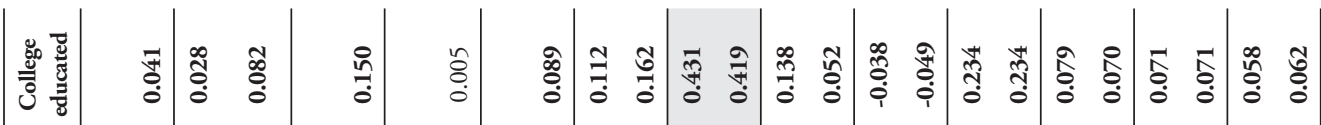

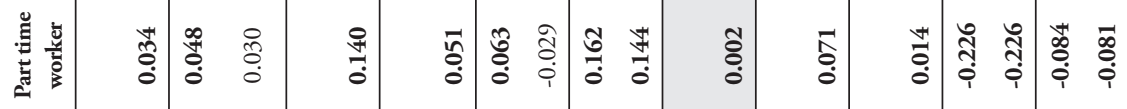

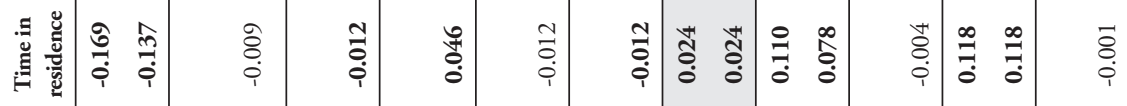

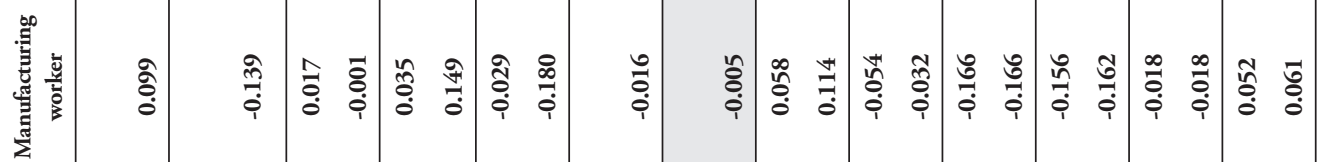

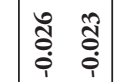

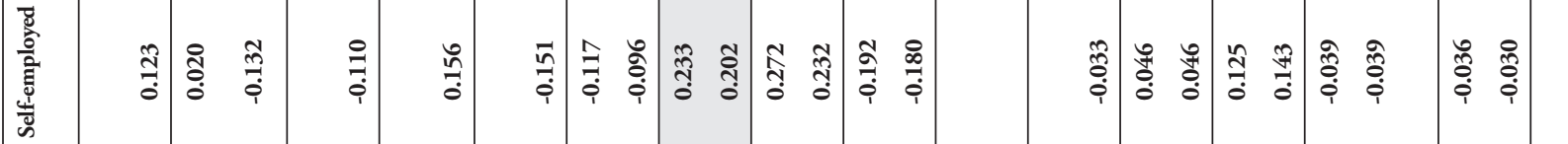

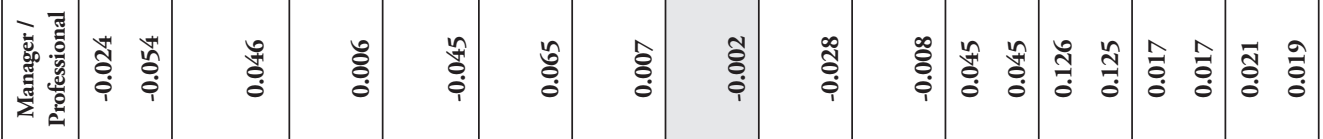

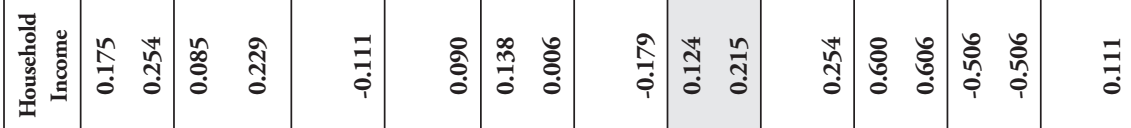

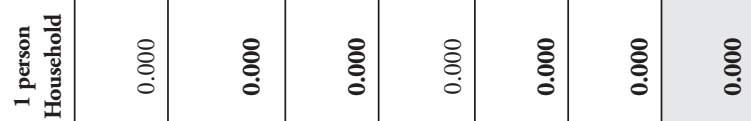

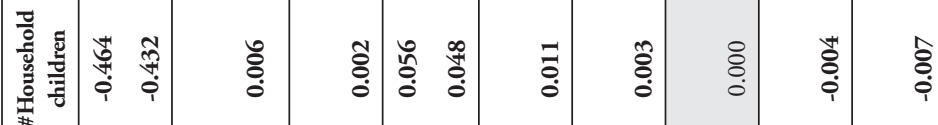

它

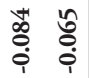

ڤิํㅇ

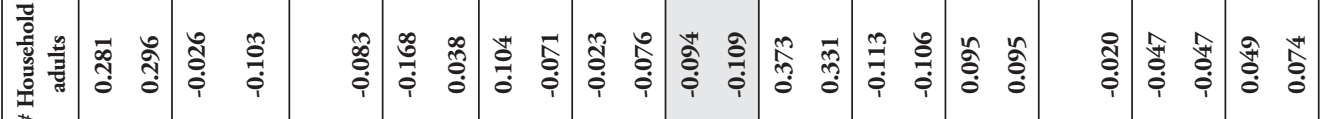

亲恶

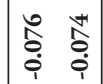

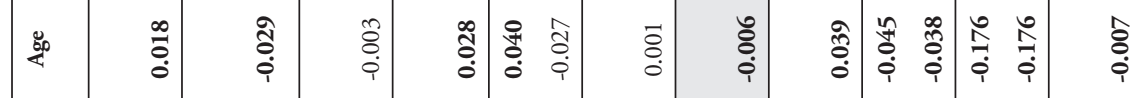

氙

สิ

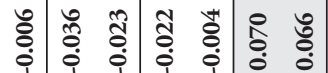

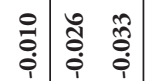

苍

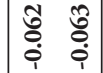

응 웅

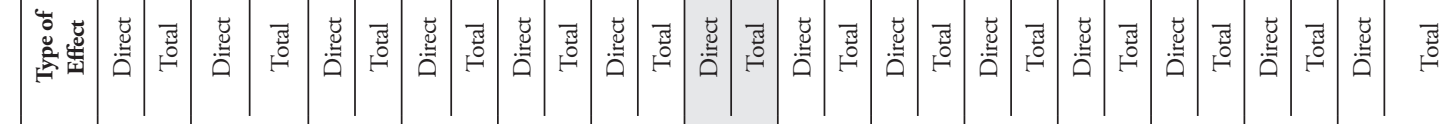

छั

ठั.

อั

ప్రి

కุ

ธิธ

ธ్రి

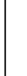




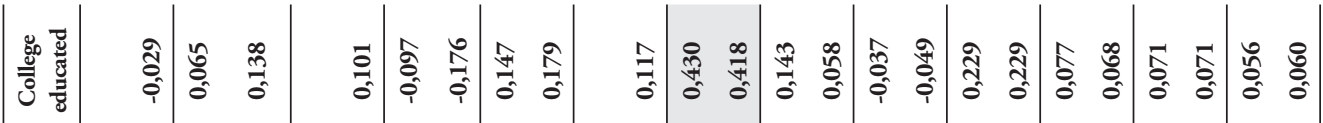

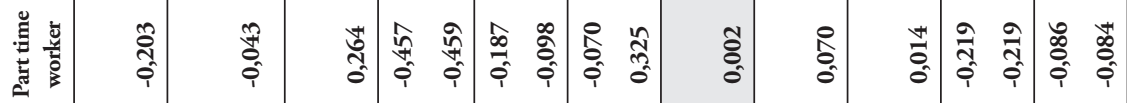

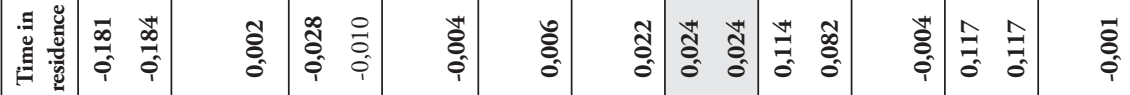

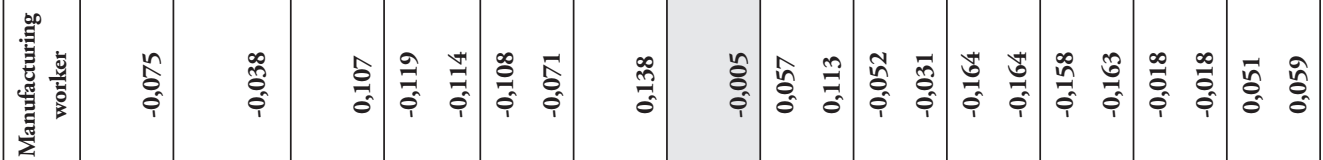

în

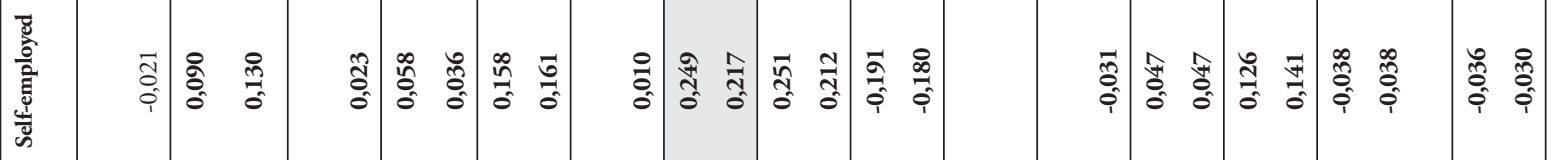

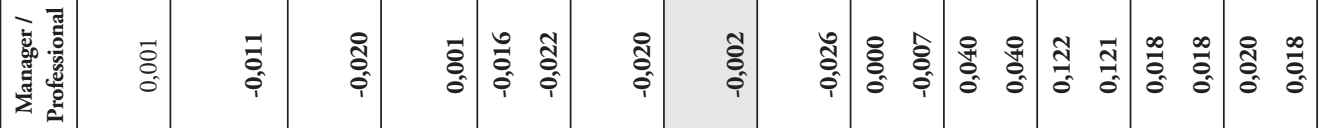

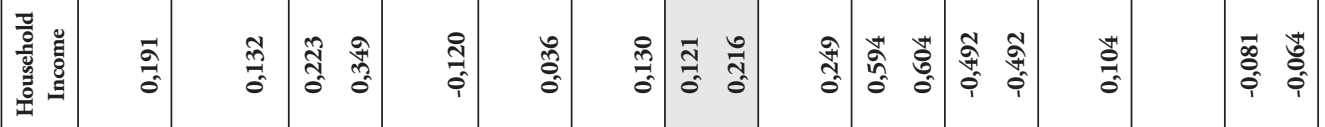

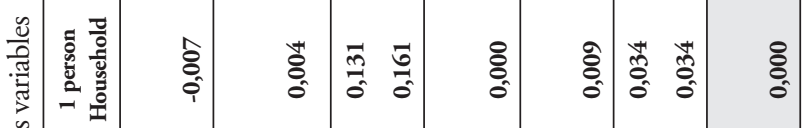

产

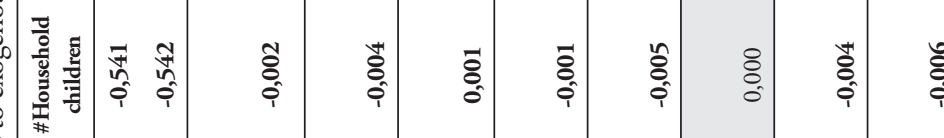

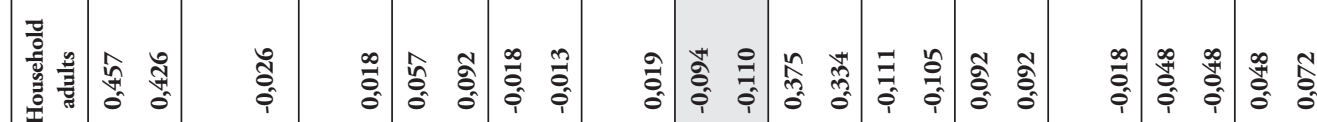

\%

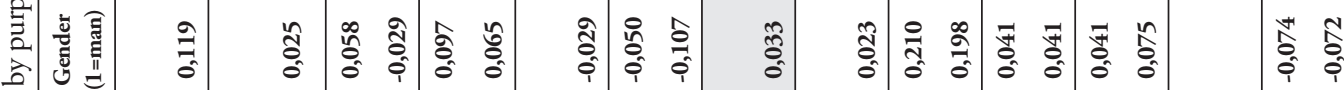

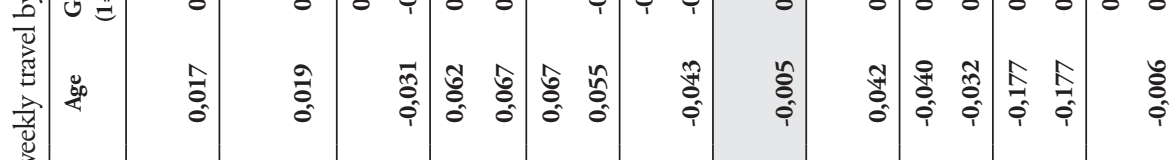

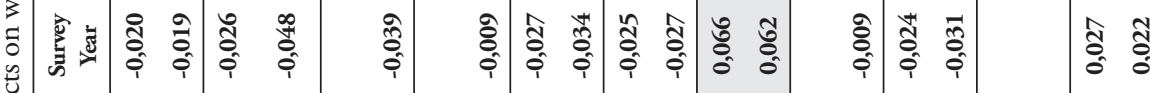

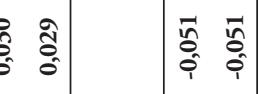

号:

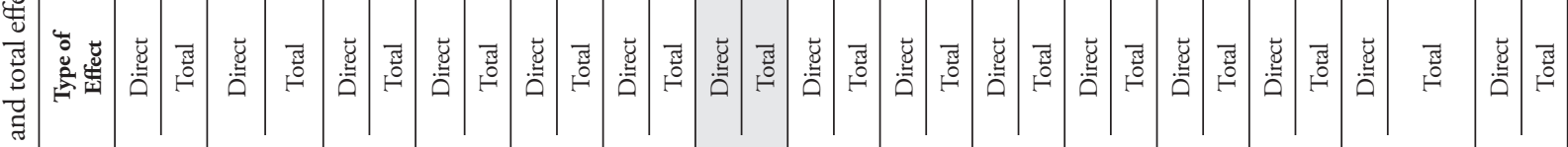

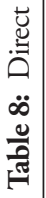
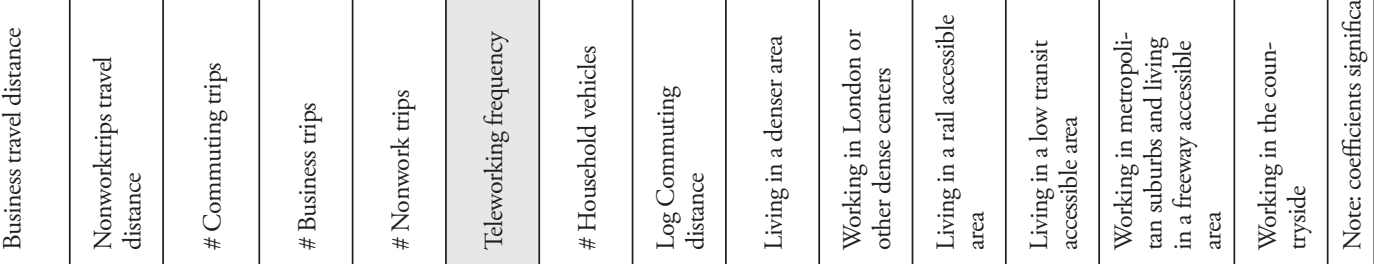


\subsection{Effects on weekly travel due to the endogenous variables}

Table 9 and Table 10 report the main findings for the standardized effects of the endogenous variables obtained from the models of weekly travel by mode and by purpose, respectively. The relationships estimated in the models are shown in Figure 2 and Figure 3, which provide a visual summary of the standardized effects due to the endogenous variables in the form of path diagrams.

Table 9 shows that home teleworking frequency increases the weekly distance travelled for all modes, indicating that teleworking is not an effective travel demand management strategy, quite the contrary. This in turn suggests that home teleworking has a complementarity effect on travel, corroborating the findings of Zhu (2012), who argued that teleworkers had larger travel budgets. Looking at the total effects of teleworking on the weekly distances travelled, the strongest effect is found for active modes followed by car, while the effect for transit modes is substantially weaker. The positive effect on distance travelled by active modes is mainly a consequence of the positive effect of teleworking on the number of trips by active modes. This result is in accordance with findings by Pendyala et al. (1991) and Saxena and Mokhtarian (1997), which point to the fact that teleworkers tend to have a smaller activity space centered around their house in the days they work from home. On the contrary, the effect of teleworking on weekly travel by car suggests that although teleworkers may make fewer car trips, they travel longer distances. These results also indicate that although teleworking frequency increases travel, the stronger determinants of mobility are location patterns, commuting distance and motorization rates. Nevertheless, teleworkers travel more than non-teleworkers with similar location and motorization patterns.

When considering weekly travel by purpose (in Table 10), the results show that home teleworking frequency reduces weekly commuting trip frequency, but increases the number of trips for the other two purposes (i.e., business and non-work). Teleworking frequency also increases the distances travelled for all purposes, although the total effect on non-work distances travelled is not statistically significant. This indicates that teleworkers may engage in more, but shorter, non-work related trips, possibly as a result of reduced trip chaining, which is in accordance with the findings by Pendyala et al. (1991).

The direct effect of teleworking frequency on weekly travelled commuting distance travelled is positive in spite of the negative effect of teleworking on the number of commuting trips. This result suggests there may be a negative offsetting / compensation effect whereby the reduced number of trips is more than offset by longer one-way commute distances. These results, and the fact that commuting distance has a strong negative total effect on commuting trips, and a positive effect on teleworking frequency, show that individuals who live farther from work may have a greater incentive to make fewer weekly commuting trips, for example by working from home, in accordance with the hypothesis that teleworking may be, at least in the short term, a strategy to cope with longer and costlier commutes. Longer commute distances may encourage individuals to adopt home teleworking as a way of saving time and monetary cost associated with commuting to work. The higher housing costs of very large urban areas, as is the case of London, may create an additional pressure on commuters to live farther away from their urban workplaces, in suburban or peri-urban areas where housing is more affordable. Particularly relevant is the fact that workers living in denser areas and in areas with good rail accessibility have a lower probability of working from home more frequently; reinforcing the view that teleworking may be used as a strategy adopted to cope with costlier and longer commutes.

As for the other relationships, Figure 2 and Figure 3 show that there is a clear hierarchy of decisions going from longer term decisions to shorter term ones. Nevertheless, there are some feedback effects from car ownership and commuting distance to land use factors for both the residence and employment locations. Land use characteristics associated with living in more central and denser areas are associated with shorter commutes. Car ownership level is positively influenced by commuting distance, and strongly negatively influenced by land uses associated with more central and denser areas. These results are in line with existing empirical evidence, thereby reinforcing our confidence in the models. 


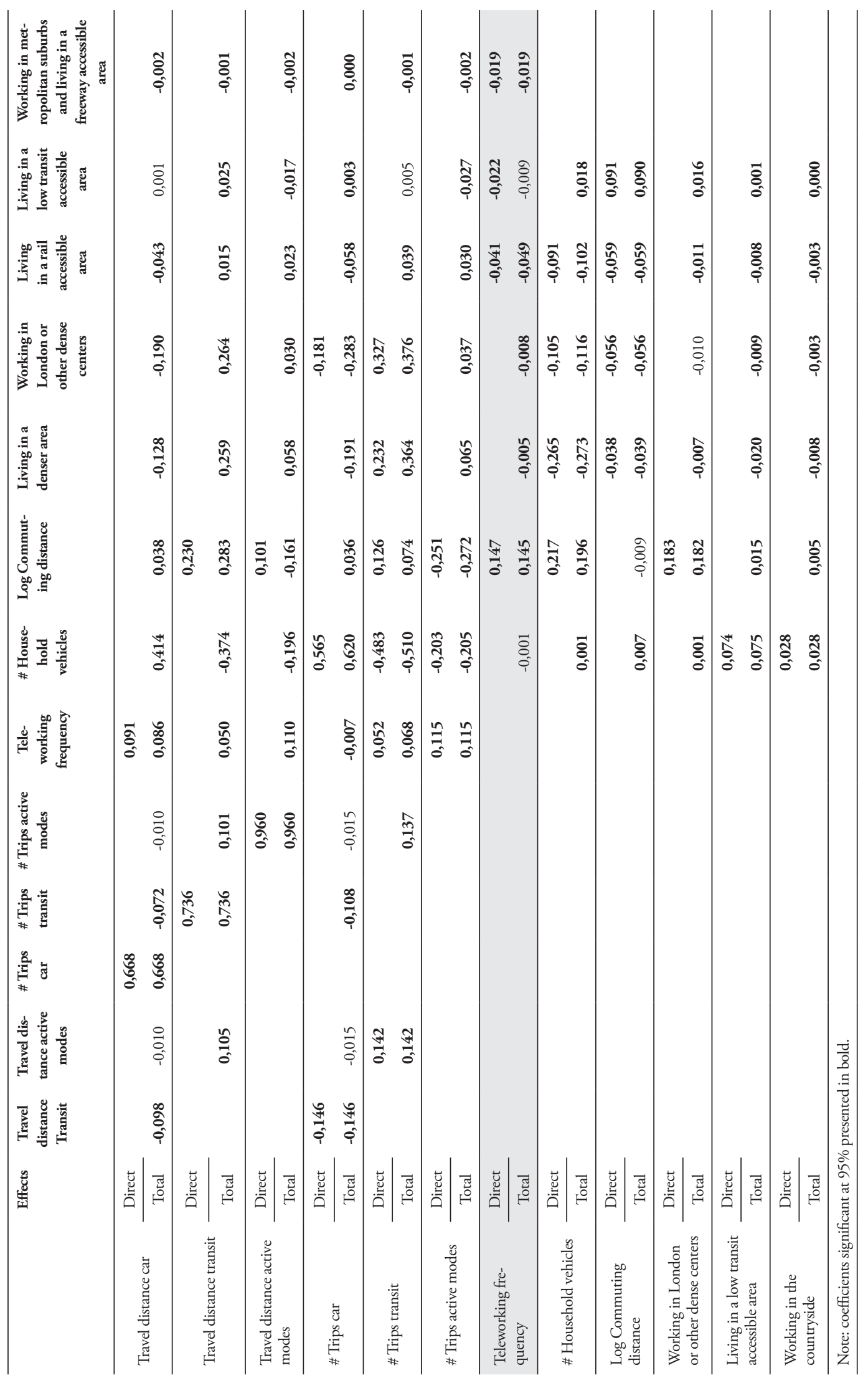




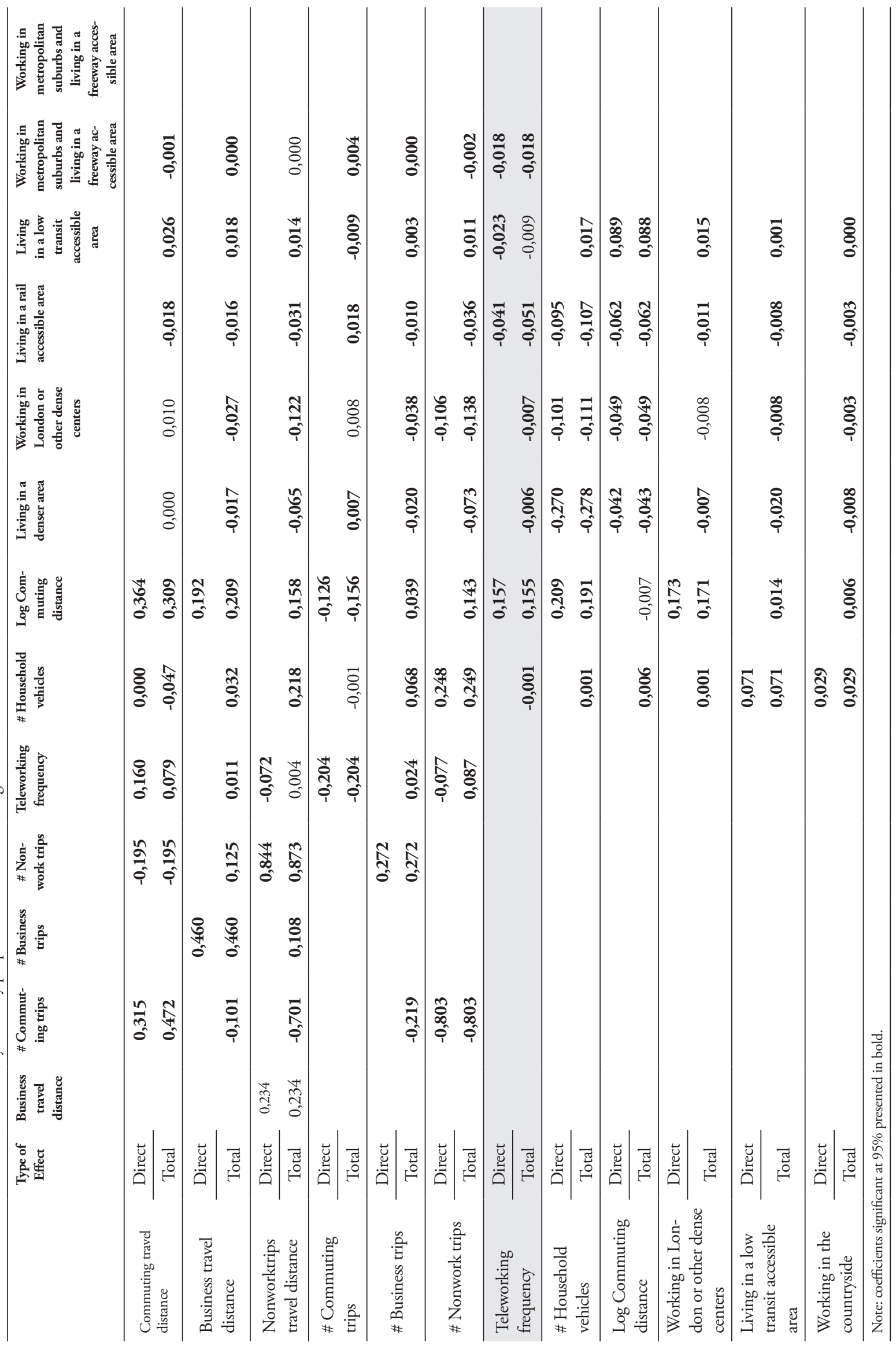




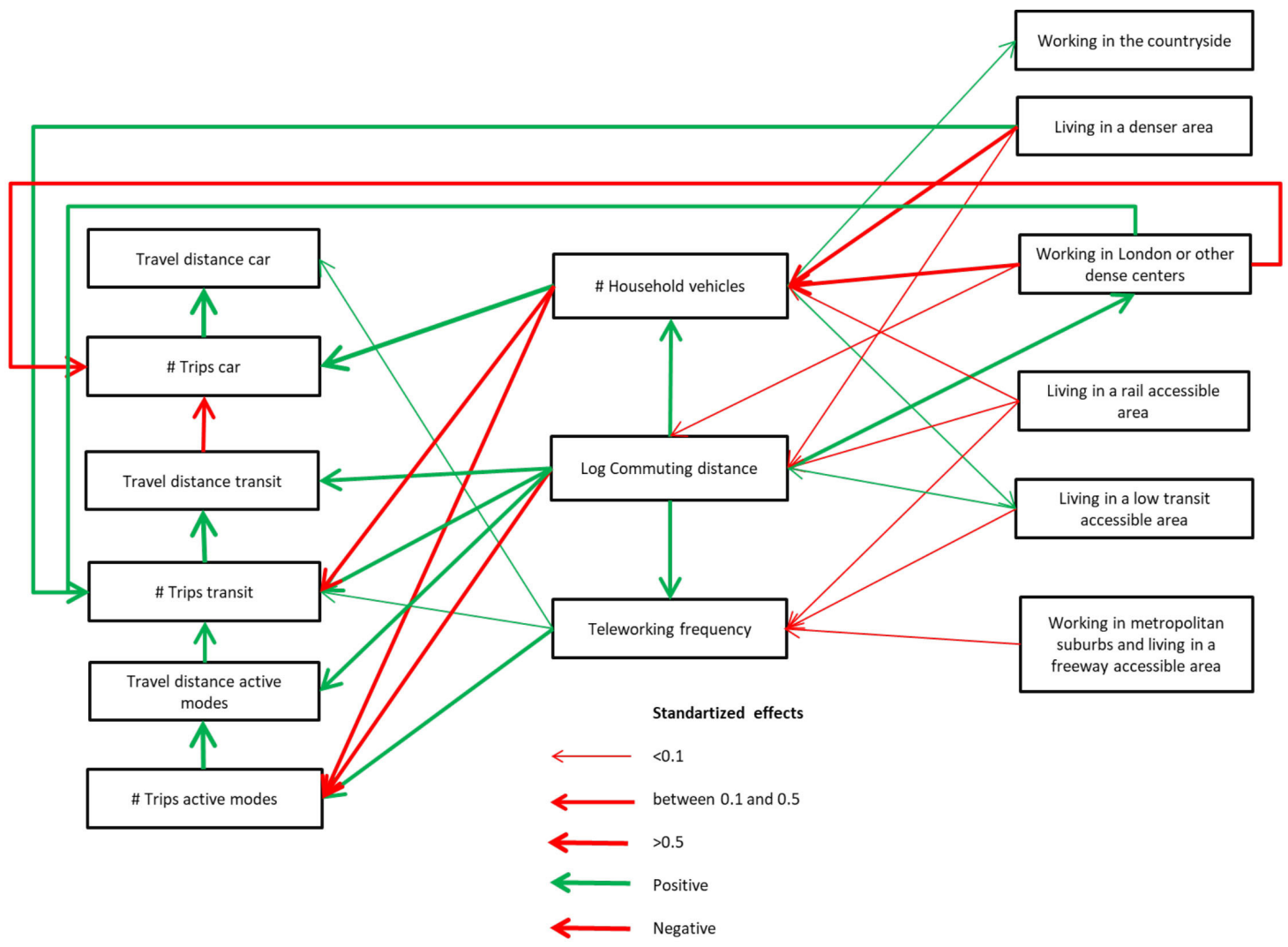

Figure 2: Causal path diagram for weekly travel by mode

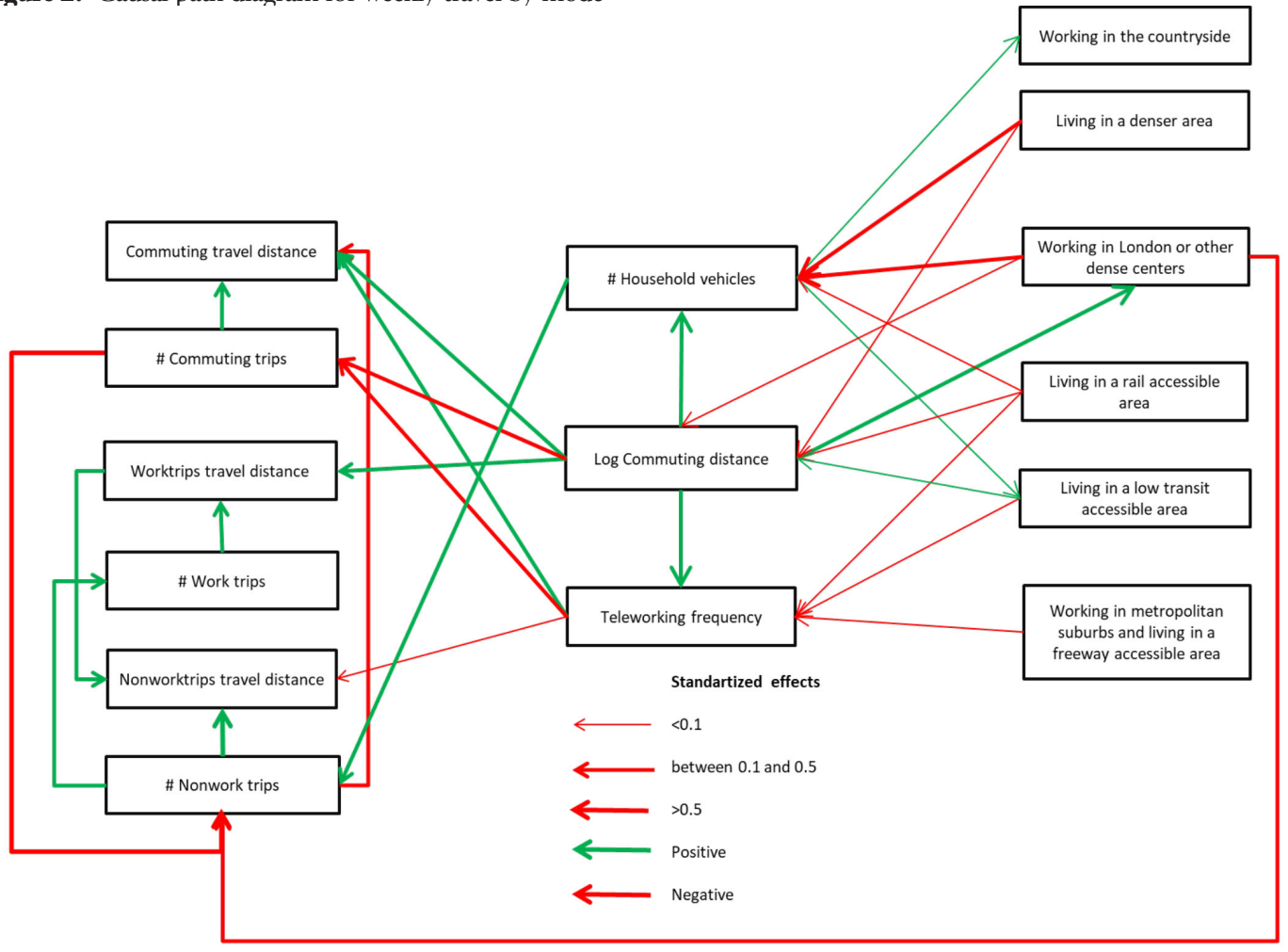

Figure 3: Causal path diagram for weekly travel by purpose 


\section{$7 \quad$ Conclusions}

This work studied the effects of home-based teleworking on the number of trips and weekly miles travelled by mode and purpose for one-worker households in Great Britain using data from the NTS for the period between 2005 and 2012. To better understand the relationship between home teleworking and travel, a path analysis model based on previous research on the relationships between travel behavior, home and workplace land use characteristics, and long- and short-term travel related decisions was estimated. The use of this modelling approach allowed us to explicitly model endogenous relations in the chain of decisions relating to home and work location, commuting distance, car ownership, teleworking frequency and weekly travel.

The main conclusions relating to home teleworking frequency point to the fact that it increases weekly miles travelled, particularly by car, while it does not reduce commuting weekly miles travelled (in spite of reducing the number of commuting trips). This indicates that the benefits of home teleworking are offset by the longer home-to-work commuting distances of teleworkers. It also suggests that home teleworking is not an effective travel demand management strategy, particularly because it seems to increase car mode share. On the other hand, teleworkers may engage in more non-work related trips centered around their homes, and since they have lower transit accessibility levels at their residence areas, they are likely to resort to either active travel (for shorter trips) or the car, which is available to them (i.e., higher levels of car ownership). The outcome therefore appears to be: travelling more by less sustainable and more polluting transport modes.

The findings also support the hypothesis that home teleworking can be used by individuals as a strategy to cope with long and costly commutes. This is supported both by the reverse causality analysis using competing model specifications, the studies discussed in the literature review (e.g., Mokhtarian \& Salomon, 1997; Ory \& Mokhtarian, 2006; Helminen \& Ristimäki, 2007), and the fact that commuting distance is the result of decisions with respect to both residence and employment locations. These decisions are considered as medium- to long-term decisions, since high transaction costs mean they are difficult to revert instantly. This does not mean that the possibility of working from home might not be considered as one decision variable when households are contemplating relocating, but it is more likely an enabler than one of the main drivers for home relocation.

These results have one potential caveat. Although the distance travelled by mode and commuting distance increase with teleworking frequency (see Table 3), there is a reduction in these indicators for the highest frequency of teleworking. This implies the possibility of very frequent teleworkers travelling less and indicates there may be some non-linear effects in the relationship between telework and travel behavior. Unfortunately, since the number of very frequent teleworkers (i.e., people engaging in teleworking three or more days a week) represents a very small proportion of the dataset (3.6\%) it is not possible, even when modelling telework frequency as an ordered variable, for the model to capture this slump and to draw definitive conclusions about its causes.

Finally, it is worth noting that this research only considers a specific group of households, namely single-worker households. Although they do not represent the majority of households, they are nonetheless a relevant group (almost half of the households with workers) of the population and allow testing our modelling approach in a less complex context such as that of two-worker households. Therefore, future research will extend and adapt the path analysis modelling framework developed in this paper to two-worker households and total household travel. 


\section{Acknowledgements}

This work received support by a STSM Grant from COST Action TU1305 Social Networks and Travel Behavior and funding from the project "Green Lifestyles, Alternative Models and Up-scaling Regional Sustainability” (GLAMURS, GA 613420) of the European Union's Seventh Framework Program FP7. The comments of two anonymous referees, to whom the authors are grateful, helped to improve this paper substantially. 


\section{References}

Choo, S., Mokhtarian, P., \& Salomon, I. (2005). Does telecommuting reduce vehicle-miles traveled? An aggregate time series analysis for the U.S. Transportation, 32, 37-64. doi.org/10.1007/s11116004-3046-7

Bollen, K. A. (1989). Structural equations with latent variables. Hoboken: Wiley

de Abreu e Silva, J., Golob, T. F., \& Goulias, K. G. (2006). The effects of land-use characteristics on residence and employment location and travel behavior of urban adult workers. Transportation Research Record, 1977, 121-131. doi.org/10.3141/1977-17

de Abreu e Silva, J., Morency, C., \& Goulias, K. G. (2012). Using structural equations modeling to unravel the influence of land use patterns on travel behavior of workers in Montreal. Transportation Research Part A: Policy and Practice, 48(8), 1252-1264. doi.org/10.1016/j.tra.2012.05.003

de Graaff, T., \& Rietveld, P. (2004). ICT and substitution between out-of-home and at-home work: The importance of timing. Environment and Planning A, 36(5), 879-896. doi.org/10.1068/a3693

Ettema, D. (2010). The impact of telecommuting on residential relocation and residential preferences: A latent class modelling approach. Journal of Transport and Land Use, 3(1), 7-24. http://dx.doi. org/10.5198/jtlu.v3i1.61

Giuliano, G. (1989). Research policy and review 27. New directions for understanding transportation and land use. Environment and Planning A, 21(2),145-159. doi.org/10.1068/a210145

Golledge, R., \& Garling, T. (2003). K. G. Goulias (Ed.), Spatial behavior in transportation modeling and planning in transportation systems planning, methods and applications. Boca Raton: CRC Press.

Golob, T. F. (2003). Structural equation modeling for travel behavior research. Transportation Research Part B: Methodological, 37(1), 1-25. doi.org/10.1016/S0191-2615(01)00046-7

Hamer, R., Kroes, E., \& Van Oosttsroom, H. (1991). Teleworking in the Netherlands: An evaluation of changes in travel behavior. Transportation, 18, 365-382. doi.org/10.1007/BF00186565

Helminen, V., \& Ristimäki, M. (2007). Relationships between commuting distance, frequency and telework in Finland. Journal of Transport Geography, 15, 331-342. doi.org/10.1016/j.jtrangeo.2006.12.004

He, S.Y., \& Hu, L. (2015). Telecommuting, income, and out-of-home activities. Travel Behavior and Society, 2(3), 131-147. doi.org/10.1016/j.tbs.2014.12.003

Henderson, D. K., Koenig, B. E., \& Mokhtarian, P. L. (1996). Using travel diary data to estimate the emissions impacts of transportation strategies: The Puget Sound Telecommuting Demonstration Project. Journal of the Air and Waste Management Association, 46, 47-57. doi.rog/10.1080/1047328 9.1996 .10467440

Hjorthol, R., \& Nossum, Å. (2007). Teleworking - Possible Interaction with Travel Patterns. In Transport, A. F. E., European Transport Conference, Leiden, Netherlands.

Jöreskog, K., \& Sörbom, D. (1993). LISREL ${ }^{\circledR}$ 8: Structural equation modelling with the SIMPLIS command language. Skokie, IL: SSI Scientific Software International.

Kaplan, D. (2000). Structural equation modeling. Foundations and extensions. Thousand Oaks, CA: Sage Publications.

Kim, S.-N., Mokhtarian, P., \& Ahn, K.-H. (2012). The Seoul of Alonso: New perspectives on telecommuting and residential location from South Korea. Urban Geography, 33(8), 1163-1191. doi. org/10.2747/0272-3638.33.8.1163

Kim, S.-N., Choo, S., \& Moktharian, P. L. (2015). Home-based telecommuting and intra-household interactions in work and non-work travel: A seemingly unrelated censored regression approach. Transportation Research Part A: Policy and Practice, 80, 197-214. doi.org/10.1016/j.tra.2015.07.018 
Kitamura, R., Nilles, J. M., Conroy, P., \& Fleming, D. M. (1991). Telecommuting as a transportation planning measure: Initial results of California pilot project. Transportation Research Record, 1285, 98-104.

Lund, J. R., \& Mokhtarian, P. L. (1994). Telecommuting and residential location: Theory and implications for commute travel in monocentric metropolis. Transportation Research Record, 1463, 10-14.

Melo, P. C., \& de Abreu e Silva, J. (2017). Home telework and household commuting patterns in Great Britain. Transportation Research Part A: Policy and Practice, 103, 1-24. doi.org/10.1016/j. tra.2017.05.011

Mokhtarian, P. L., \& Bagley, M. N. (2000). Modeling employees' perceptions and proportional preferences of work locations: The regular workplace and telecommuting alternatives. Transportation Research Part A: Policy and Practice, 34(4), 223-242. doi.org/10.1016/S0965-8564(99)00002-6

Mokhtarian, P. L., Collantes, G. O., \& Gertz, C. (2004). Telecommuting, residential location, and commute-distance traveled: Evidence from state of California employees. Environment and Planning A, 36, 1877-1897. doi.org/10.1068/a36218

Mokthtarian, P. L., Handy, S. L., \& Salomon, I. (1995). Methodological issues in the estimation of the travel, energy, and air quality impacts of telecommuting. Transportation Research Part A: Policy and Practice, 29, 283-302. doi.org/10.1016/0965-8564(94)00029-A

Mokhtarian, P. L., \& Salomon, I. (1997). Modeling the desire to telecommute: The importance of attitudinal factors in behavioral models. Transportation Research Part A: Policy and Practice, 31, 35-50. doi.org/10.1016/S0965-8564(96)00010-9

Mokhtarian, P. (2009). If telecommunication is such a good substitute for travel, why does congestion continue to get worse? Transportation Letters, 1(1), 1-17. doi.org/10.3328/TL.2009.01.01.1-17

Muhammad, S., Ottens, H. F. L., Ettema, D., \& de Jong, T. (2007). Telecommuting and residential locational preferences: A case study of the Netherlands. Journal of Housing and the Built Environment, 22(4), 339-358. doi.org/10.1007/s10901-007-9088-3

Nilles, J. M. (1991). Telecommuting and urban sprawl: Mitigator or inciter? Transportation, 18, $411-$ 432. doi.org/10.1007/BF00186567

Nelson, P., Safirova, E., \& Walls, M. (2007). Telecommuting and environmental policy: Lessons from the e-commute program. Transportation Research Part D: Transport and Environment, 12(3), 195207. doi.org/10.1016/j.trd.2007.01.011

Nurul Habib, K. M., Sasic, A., \& Zaman, H. (2012). Investigating telecommuting considerations in the context of commuting mode choice. International Journal of Sustainable Transportation, 6(6), 362-383. doi.org/10.1080/15568318.2011.621014

Ory, D. T., \& Mokhtarian, P. L. (2006). Which came first, the telecommuting or the residential relocation? An empirical analysis of causality. Urban Geography, 27, 590-609. doi.org/10.2747/02723638.27.7.590

Páez, A., \& Scott, D. M. (2007). Social influence on travel behavior: A simulation example of the decision to telecommute. Environment and Planning A, 39(3), 647-665. doi.org/10.1068/a37424

Pendyala, R. M., Goulias, K. G., \& Kitamura, R. (1991). Impact of telecommuting on spatial and temporal patterns of household travel. Transportation, 18, 383-409. doi.org/10.1007/BF00186566

Peters, P., Tijdens, K. G., \& Wetzels, C. (2004). Employees' opportunities, preferences, and practices in telecommuting adoption. Information and Management, 41(4), 469-482. doi.org/10.1016/S03787206(03)00085-5

Poury, Y. D., \& Bhat, C. R. (2003). On modeling choice and frequency of home-based telecommuting. Transportation Research Record, 1858, 55-60. doi.org/10.3141/1858-08

Rhee, H. J. (2008). Home-based telecommuting and commuting behavior. Journal of Urban Economics, 
63(1),198-216. doi.org/10.1016/j.jue.2007.01.007

Salomon, I. (1998). Technological change and social forecasting: The case of telecommuting as a travel substitute. Transportation Research Part C: Emerging Technologies, 6(1-2), 17-45. doi.org/10.1016/ S0968-090X(98)00006-0

Saxena, S., \& Mokhtarian, P. L. (1997). The impact of telecommuting on the activity spaces of participants and their households. Geographical Analysis, 29, 124-144. doi.org/10.1111/j.1538-4632.1997. tb00952.x

Singh, P., Paleti, R., Jenkins, S., \& Bhat, C. R. (2013). On modeling telecommuting behavior: Option, choice, and frequency. Transportation, 40, 373-396. doi.org/10.1007/s11116-012-9429-2

Schermelleh-Engel, K., Moosbrugger, H., \& Müller, H. (2003). Evaluating the fit of structural equation models: Tests of significance and descriptive goodness-of-fit measures. Methods of Psychological Research Online, 8(2), 23-74.

Schumaker, R., \& Lomax, R. G. (2004). A beginner's guide to structural equation modeling, 2nd Edition. Mahwah: Lawrence Erlbaum Associates.

Tayyaran, M. R., \& Khan, A. M. (2003). The effects of telecommuting and intelligent transportation systems on urban development. Journal of Urban Technology, 10(2), 87-100. doi.org/10.1080/106 3073032000139714

Wells, K., Douma, F., Loimer, H., Olson, L., \& Pansing, C. (2001). Telecommuting implications for travel behavior: Case studies from Minnesota. Transportation Research Record, 1752, 148-156. doi. org/10.3141/1752-20

Yen, J. R. (2000). Interpreting employee telecommuting adoption: An economics perspective. Transportation, 27(1),149-164. doi.org/10.1023/A:1005200513201

Zhu, P. (2012). Are telecommuting and personal travel complements or substitutes? The Annals of Regional Science, 48, 619-639. doi.org/10.1007/s00168-011-0460-6

Zhu, P. (2013). Telecommuting, household commute and location choice. Urban Studies, 50, 24412459. doi.org/10.1177/0042098012474520

Zhu, P., \& Mason, S. G. (2014). The impact of telecommuting on personal vehicle usage and environmental sustainability. International Journal of Environmental Science and Technology, 11, 2185-2200. doi.org/10.1007/s13762-014-0556-5 